\title{
A Seventeenth Century Shoemaker's Account Book
}

Mrs. Christine Adams Jones has recently presented to the Business Historical Society a rare little account book of one of her ancestors. It was kept by Jacob Adams, a farmer-shoemaker of Newbury, Massachusetts, between the years 1673 and 1693. In an article about this account book in the issue of the Bulletin of December, 1935, Mrs. Blanche Hazard Sprague, the outstanding authority on early shoemaking in this region, writes that "these accounts represented (by 95 years) the oldest first-hand records of shoemaking in New England which I had ever seen in my continuous research since 1906 on the shoe industry in this region."

The book constitutes a rare record of early American business. Sketchy though it is and difficult as it is to decipher, it affords not a little insight into a particular trade, that of the shoemaker, and indeed it suggests much about how the business of the colonial village was carried on. Such fragments, which the historian pieces together, are the indispensable materials for reconstructing the economic life of those early times.

1 See her book entitled The Organization of the Boot and Shoe Industry in Massachusetts before 187.5 (Cambridge, 1921).

\section{Meeting of the Council of the}

\section{Business Historical Society}

The annual meeting of the Council of the Society was held at the Parker House in Boston on May 8. The following members were present: Messrs. Adams, David, Gras, Higgins, and Kiley, Council members, and Mr. Navin, Clerk.

The Executive Secretary summarized the minutes of the last 